\title{
Concurrent neoadjuvant chemoradiotherapy could improve survival outcomes for patients with esophageal cancer: a meta- analysis based on random clinical trials
}

\author{
Baoxing Liu, ${ }^{1, *}$, Yacong Bo ${ }^{2, *}$, Kunlun Wang ${ }^{1}$, Yang Liu ${ }^{1}$, Xiance Tang ${ }^{1}$, Yan Zhao ${ }^{1}$, \\ Erjiang Zhao ${ }^{1}$ and Ling Yuan ${ }^{1}$ \\ ${ }^{1}$ Affiliated Tumor Hospital of Zhengzhou University, Henan Tumor Hospital, Zhengzhou, Henan, China \\ ${ }^{2}$ Department of Nutrition and Food Hygiene, College of Public Health, Zhengzhou University, Affiliated Tumor Hospital of \\ Zhengzhou University, Henan Tumor Hospital, Zhengzhou, China \\ * These authors have contributed equally to this work \\ Correspondence to: Ling Yuan, email: hnyl2001@126.com \\ Keywords: neoadjuvant concurrent chemoradiotherapy; esophageal cancer; overall survival; R0 resection rate; progression-free \\ survival \\ Received: October 05, $2016 \quad$ Accepted: January 09, $2017 \quad$ Published: January 15, 2017
}

\section{ABSTRACT}

Background: The long-term survival benefit of concurrent neoadjuvant chemoradiotherapy in patients with resectable esophageal cancer remains controversial. In the present study, we conducted a meta-analysis to assess these effectiveness.

Methods: We searched for most relevant studies published up to the end of August 2016, using Pubmed and web of knowledge. And additional articles were identified from previous meta-analysis. The hazard ratio (HR, for overall survival and progression free survival) or risk ratio ( $R R$, for $\mathbf{R O}$ resection) with its corresponding $95 \%$ confidence interval (CI) were used to assess the pooled effect.

Results: Twelve articles including 1756 patients were included in the metaanalysis. Concurrent neoadjuvant chemoradiotherapy followed by surgery was associated with significantly improved overall survival ( $\mathrm{HR}=0.76,95 \% \mathrm{CI}=0.68$ $0.86)$, progression survival $(H R=0.69,95 \% C I=0.59-0.81)$, and $R 0$ resection rate $(R R=1.17,95 \% C I=1.03-1.33)$. Subgroup analysis suggested that concurrent neoadjuvant chemoradiotherapy could improve overall survival outcome for squamous cell carcinoma $(\mathrm{HR}=0.73,95 \% \mathrm{CI}=0.61-0.88)$ but not those for adenocarcinoma $(\mathrm{HR}=0.72,95 \% \mathrm{CI}=0.48-1.04)$.

Conclusion: Our findings suggested that concurrent neoadjuvant chemoradiotherapy was associated with a significant survival benefit in patients with esophageal cancer.

\section{INTRODUCTION}

With more than 456,000 newly diagnosed cases and 400,000 related deaths annually, esophageal cancer is the tenth most common cancer and the eighth leading cause of cancer-related deaths worldwide. [1, 2] Since most esophageal cancer patients are diagnosed at the advanced stages, the 5-year survival rate is less than $20 \%$. [3] Despite surgical care and improvements in preoperative staging, surgery alone leads to relatively few long-term survivors. [4] A great number of patients who underwent esophagectomy continue to die as a result of tumor recurrence. [5]

Adjuvant therapies, with either radiotherapy or chemotherapy, have not shown survival any benefits. [5] This, along with the evident difficulties of administering radiotherapy and chemotherapy after resection for esophageal cancer, makes recent trials focus on the role of neoadjuvant treatment, especially the concurrent neoadjuvant chemoradiotherapy (NCRT). A recent metaanalysis showed that concurrent NCRT was associated with improved 1-, 3- and 5-year survival rate. [6] 
Table 1: Chemoradiotherapy regimens in randomized trials included in the meta-analysis

\begin{tabular}{|c|c|c|c|c|c|c|}
\hline \multirow{2}{*}{ First author } & \multirow{2}{*}{ Year } & \multicolumn{3}{|c|}{ Sample size } & \multirow{2}{*}{ Pathology } & \multirow{2}{*}{ Neoadjuvant treatment schedule } \\
\hline & & NCRTS & SA & total & & \\
\hline Wlsh & 1996 & 58 & 55 & 113 & $\mathrm{AC}$ & $\begin{array}{l}\text { Cis } 75 \mathrm{mg} / \mathrm{m} 2 \text { on days } 7 \text { and } 42 ; \mathrm{FU} 15 \mathrm{mg} / \mathrm{kg} \text { on days } 1-5 \text { and } 36-40 \\
40 \mathrm{~Gy} \text { in } 15 \text { fractions over } 3 \text { weeks }\end{array}$ \\
\hline Shapiro & 2015 & 178 & 188 & 366 & $\mathrm{AC}$ and $\mathrm{SCC}$ & $\begin{array}{l}\text { Carboplatin (AUC } 2 \mathrm{mg} / \mathrm{mL} \text { per min) and paclitaxel }\left(50 \mathrm{mg} / \mathrm{m}^{2} \text { of }\right. \\
\text { body-surface area) were administered intravenously for five cycles, } \\
\text { starting on days } 1,8,15,22 \text {, and } 29 \text {. A total concurrent radiation } \\
\text { dose of } 41 \cdot 4 \text { Gy was given in } 23 \text { fractions of } 1 \cdot 8 \mathrm{~Gy} \text {, on } 5 \text { days per } \\
\text { week (excluding weekends), starting on the fi rst day of the first } \\
\text { chemotherapy cycle. }\end{array}$ \\
\hline Mariette & 2014 & 81 & 89 & 170 & $\mathrm{AC}$ and $\mathrm{SCC}$ & $\begin{array}{l}\text { A total dose of } 45 \text { Gy was delivered in } 25 \text { fractions (five fractions } \\
\text { per week) over } 5 \text { weeks. Chemotherapy was delivered concomitantly } \\
\text { and composed of two cycles of fluorouracil (FU) and cisplatin. FU } \\
800 \mathrm{mg} / \mathrm{m} 2 \text { per } 24 \text { hours was administered as a continuous infusion } \\
\text { from days } 1 \text { to } 4 \text { and } 29 \text { to } 32 \text {. Cisplatin } 75 \mathrm{mg} / \mathrm{m} 2 \text { was delivered by } \\
\text { infusiononday } 1 \text { or } 2 \text { and againonday } 29 \text { or } 30 \text {. }\end{array}$ \\
\hline $\mathrm{Lv}$ & 2010 & 80 & 80 & 160 & $\mathrm{SCC}$ & $\begin{array}{l}\text { Radiation was delivered in a total dose of } 40 \text { Gy ( } 20 \text { fractions at } \\
2 \text { Gy per fraction). For chemotherapy, } 2 \text { cycles were administered } \\
\text { on days 1-3 and days 22-24 of radiotherapy. A paclitaxel } \\
\text { (PTX)+cisplatin (DDP) regimen was used, including PTX (135 mg/ } \\
\text { m2 per day) administered as a short-term infusion on day } 1 \text { of each } \\
\text { cycle, while DDP (20 mg/m2 per day) was delivered as a continuous } \\
\text { infusion over } 24 \mathrm{~h} \text { on days } 1-3 \text { of each cycle. }\end{array}$ \\
\hline Burmeister & 2005 & 128 & 128 & 256 & $\mathrm{AC}$ and $\mathrm{SCC}$ & $\begin{array}{l}\text { Cis } 80 \mathrm{mg} / \mathrm{m} 2 \text { on day } 1 ; \mathrm{FU} 800 \mathrm{mg} / \mathrm{m} 2 \text { per day on days } 1-4,35 \mathrm{~Gy} \\
\text { in } 15 \text { fractions over } 3 \text { weeks }\end{array}$ \\
\hline $\mathrm{Cao}$ & 2009 & 118 & 118 & 236 & SCC & $\begin{array}{l}\text { Cis } 20 \mathrm{mg} / \mathrm{m} 2 \text { per day on days } 1-5 ; \mathrm{FU} 500 \mathrm{mg} / \mathrm{m} 2 \text { per day on days } \\
1-5 ; \mathrm{mitomycin} 10 \mathrm{mg} / \mathrm{m} 2 \text { per day on day } 1 \\
40 \mathrm{~Gy}, 2 \text { Gy per fraction over } 4 \text { weeks } \\
\end{array}$ \\
\hline Lee & 2004 & 51 & 50 & 101 & $\mathrm{SCC}$ & $\begin{array}{l}\text { Cis } 60 \mathrm{mg} / \mathrm{m} 2 \text { on days } 1 \text { and } 22 ; \mathrm{FU} 1000 \mathrm{mg} / \mathrm{m} 2 \text { per day on days } \\
2-5.45 \cdot 6 \mathrm{~Gy}, 1 \cdot 2 \mathrm{~Gy} \text { per fraction over } 28 \text { days }\end{array}$ \\
\hline Tepper & 2008 & 30 & 26 & 56 & $\mathrm{AC}$ and $\mathrm{SCC}$ & $\begin{array}{l}\text { Cis } 60 \mathrm{mg} / \mathrm{m} 2 \text { on days } 1 \text { and } 29 ; \mathrm{FU} 1000 \mathrm{mg} / \mathrm{m} 2 \text { per day on days } \\
1-4 \text { and } 29-32 \\
50 \cdot 4 \mathrm{~Gy}, 1 \cdot 8 \mathrm{~Gy} \text { per fraction over } 5 \cdot 6 \text { weeks }\end{array}$ \\
\hline Natsugoe & 2006 & 22 & 23 & 45 & SCC & $\begin{array}{l}\text { A total radiation dose of } 40 \mathrm{~Gy} \text { was applied, in } 2-\mathrm{Gy} \text { fractions } \\
\text { delivered } 5 \text { days/week for } 4 \text { weeks to the media stinum and neck. } \\
\text { In the same period, intravenous chemotherapy was performed using } \\
\text { cisplatin ( } 7 \mathrm{mg} \text { over } 2 \mathrm{~h} \text { ) and } 5 \text {-fluorouracil (5-FU; } 350 \mathrm{mg} \text { over } \\
24 \mathrm{~h} \text { ). }\end{array}$ \\
\hline Urba & 2007 & 50 & 50 & 100 & $\mathrm{AC}$ and $\mathrm{SCC}$ & $\begin{array}{l}\text { Cis } 20 \mathrm{mg} / \mathrm{m} 2 \text { on days } 1-5 \text { and } 17-21 ; \mathrm{FU} 300 \mathrm{mg} / \mathrm{m} 2 \text { on days } \\
1-21 ; \text { vinblastine } 1 \mathrm{mg} / \mathrm{m} 2 \text { on days } 1-4 \text { and } 17-2045 \mathrm{~Gy}, 1 \cdot 5 \mathrm{~Gy} \\
\text { per fraction over } 3 \text { weeks }\end{array}$ \\
\hline Hsu & 2013 & 46 & 38 & 84 & SCC & $\begin{array}{l}\text { The chemotherapy regimen included } 80 \mathrm{mg} / \mathrm{m} 2 \text { of cisplatin } \\
\text { intravenously on day } 1 \text { followed by } 600 \mathrm{mg} / \mathrm{m} 2 / \mathrm{day} \text { of } 5 \text {-fluorouracil } \\
\text { and } 90 \mathrm{mg} / \mathrm{m} 2 / \text { day of leucovorin given by continuous intravenous } \\
\text { infusion on days } 1-4 \text {, concurrent with } 45.0-50.4 \text { Gy of externalbeam } \\
\text { radiation at } 1.8-2.0 \text { Gy per fraction. }\end{array}$ \\
\hline Apinop & 1994 & 35 & 34 & 69 & $\mathrm{SCC}$ & $\begin{array}{l}\text { Cis } 100 \mathrm{mg} / \mathrm{m} 2 \text { on days } 1 \text { and } 29 ; \mathrm{FU} 1000 \mathrm{mg} / \mathrm{m} 2 \text { per day on days } \\
1-4 \text { and } 29-32 \\
40 \text { Gy, } 2 \text { Gy per fraction over } 4 \text { weeks }\end{array}$ \\
\hline
\end{tabular}

NCRTS, neoadjuvant chemoradiotherapy followed by surgery; SA, surgery alone; SCC, squamous cell carcinoma; AC, adenocarcinoma; Cis, cisplatin; FU, fluorouracil

However, the outcomes of their study are pooled risk ratio (RR), which did not consider the survival time, Moreover, analysis for R0 resection and progression-free survival were not conducted.

Several Randomized clinical trials (RCTs) have investigated the effect of concurrent NCRT on operable esophageal cancer. However, these results are controversial. A meta-analysis pooling current literatures might be helpful for confirming such effect. Therefore, the aim of the current study was to determine whether concurrent NCRT plus surgery is superior to surgery alone for operable esophageal cancer.

\section{RESULTS}

\section{Literature search and study characteristics}

In total, 12 RCTs including 1756 patients (877patients were treated with concurrent NCRT plus surgery and 879 patients were treated with surgery alone) were included in the meta analysis. [7-18] The detailed processes of our literature search are displayed in Figure 1. Of these 12 studies, twelve studies reported the outcome of overall survival, six studies reported the $\mathrm{R} 0$ resection rate, and four studies reported the progression-free survival. The main characters of these studies are presented in Table 1. 
Table 2: Subgroup analysis for overall survival of concurrent NCRT plus surgery vs. surgery alone.

\begin{tabular}{|l|c|c|c|c|c|}
\hline \multirow{2}{*}{ Subgroups } & \multirow{2}{*}{ Included studies } & \multicolumn{2}{c|}{ Sample size } & \multirow{2}{*}{ HR (95 \% CI) } & \multirow{2}{*}{ P value for heterogeneity } \\
\cline { 3 - 5 } & & NCRTS & SA & & \\
\hline Geographical location & & & & & \\
\hline West & 6 & 525 & 536 & $0.74(0.64-0.85)$ & 0.081 \\
\hline East & 6 & 352 & 343 & $0.82(0.67-1.00)$ & 0.714 \\
\hline Histology & & & & & \\
\hline SCC & 8 & 438 & 436 & $0.76(0.63-0.90)$ & 0.508 \\
\hline AC & 3 & 272 & 274 & $0.72(0.48-0.1 .08)$ & 0.021 \\
\hline AC+SCC & 3 & 161 & 165 & $0.80(0.62-1.04)$ & 0.182 \\
\hline
\end{tabular}

NCRTS, neoadjuvant chemoradiotherapy followed by surgery; SA, surgery alone; SCC, squamous cell carcinoma; AC, adenocarcinoma; HR, hazard ratio; CI: confidence interval.

\section{Primary outcome}

The primary outcome overall survival was reported in twelve RCTs. Compared with the surgery alone group, the pooled hazard ratio (HR) for the concurrent NCRT plus surgery group was 0.76 (95\% CI 0.68-0.86) (Figure 2). As presented in Table 2, when we carried out the stratified analysis by geographical location, significant results were observed both in the west and east $(\mathrm{HR}=$ $0.75,95 \% \mathrm{CI}=0.64-0.85$ and $\mathrm{HR}=0.82,95 \% \mathrm{CI}=0.67$ 0.88 , respectively). Furthermore, the subgroup analysis by histological type showed that concurrent NCRT plus surgery can improve squamous cell carcinoma (SCC) patients $(\mathrm{HR}=0.73,95 \% \mathrm{CI}=0.61-0.88)$, but not adenocarcinoma $(\mathrm{AC})$ patients $(\mathrm{HR}=0.72,95 \% \mathrm{CI}=0.48$ $1.04)$ or $\mathrm{AC}+\mathrm{SCC}$ patients $(\mathrm{HR}=0.80,95 \% \mathrm{CI}=0.62$ $1.04)$.

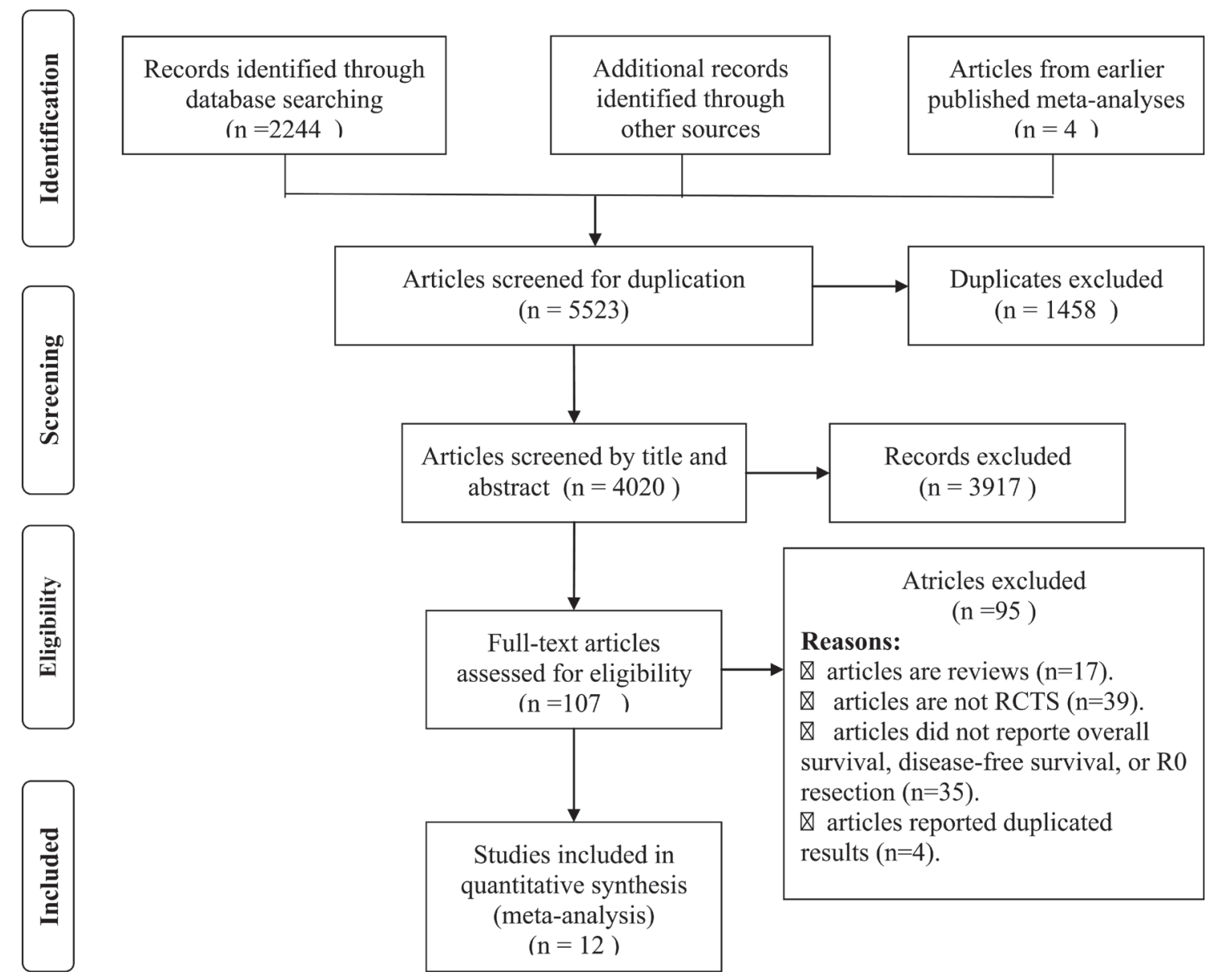

Figure 1: The flow diagram of screened, excluded, and analyzed publications 


\section{Secondary outcomes}

Figure 3 show Forest plots for the secondary outcomes, including the $\mathrm{R} 0$ resection rate and progressionfree survival. Four RCTs reported the progression-free survival, indicating a statistically significant difference (HR 0.69, 95\% CI 0.59-0.81, Figure 3B) for the concurrent NCRT plus surgery group compared to the surgery alone group. Six RCTs reported the R0 resection rate, indicating a statistically significant difference (RR $1.17,95 \% \mathrm{CI}$ 1.03-1.33, Figure 3A) for the concurrent NCRT plus surgery group compared to the surgery alone group.

\section{Publication bias}

A funnel plot of the effect size for overall survival was found to be symmetrical (Figure. 4), indicating little publication bias. The $P$ value based on Egger's test for overall survival was $0.990(t=-0.01)$, which also showed no publication bias existed.

\section{DISCUSSION}

The results of present meta-analysis showed that concurrent NCRT was associated with improved overall survival, progression-free survival, and $\mathrm{R} 0$ resection rate in patients with esophageal cancer. And this is the largest meta-analysis to explore the survival benefit with concurrent NCRT plus surgery versus surgery alone.

Several potential explanations exist for the improved effects of concurrent NCRT. First, chemotherapy has a radio sensitizing effect, which can enhance the local effects of concurrent radiotherapy, reducing the possibility of tumor spreading from the primary tumor site prior to surgery. Second, concurrent chemoradiotherapy may have the ability to inhibit the proliferation of tumor cells in the primary lesion site, decreasing the length of preoperative treatment required.

Our subgroup analysis also demonstrated that concurrent NCRT plus surgery significantly improved overall survival outcome for patients in the west. Whereas in the east, concurrent NCRT plus surgery was only associated with improved overall outcome with a
Study

ID
$\%$

HR $(95 \% \mathrm{Cl}) \quad$ Weight

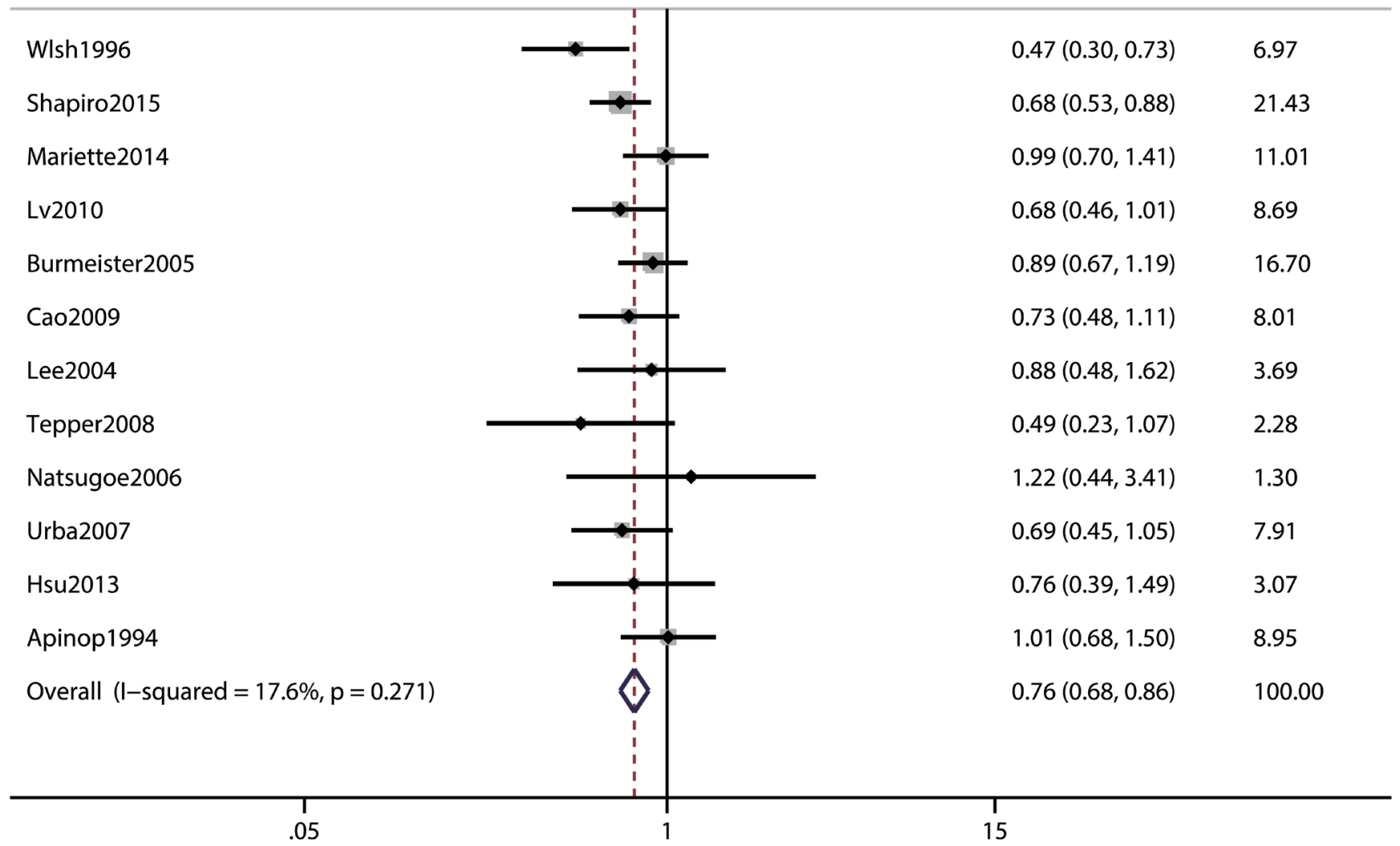

Figure 2:Meta analysis comparing the overall survival between neoadjuvant chemoradiotherapy plus surgery and surgery alone. $\mathrm{CI}$, confidence interval; $\mathrm{HR}$, hazard ratio. 
borderline significant. It might be ascribed the different genetic backgrounds and/or ethnicities of the participants, which should be further investigated with well-designed multicenter RCTs from different ethnics. Moreover, in order to verify the effect of concurrent NCRT, subgroup analysis based on histology was also introduced. Through this subgroup analysis, we found that concurrent NCRT plus surgery improved the overall survival outcome for SCC patients, but not for AC patients or AC+SCC patients. Several explanations may partly explain the reasons. Firstly, participants with SCC may gain more benefits from concurrent NCRT plus surgery than those with AC. Secondly, SCC patients have a greater potential to involve the superior mediastinum and cervical region than AC patients, which is more difficult for aggressive intrathoracic and cervical nodal dissection to be carried out. Besides, SCC is more sensitive to radiotherapy and chemotherapy than AC. [6] Thus, the addition of chemoradiotherapy to the treatment regime might have improved therapeutic outcome.

In order to determine the reasons that patients with resectable esophageal cancer could receive a survival advantage from concurrent NCRT, we chose the R0 resection rate as a secondary outcome. The final results revealed that the $\mathrm{RR}$ of $\mathrm{R} 0$ resection rate favored the group of concurrent NCRT, which approximated the results of previous study. [19] However, they included not only concurrent NCRT but also sequential NCRT, suggesting that the combination of concurrent and sequential NCRT rather than concurrent NCRT was the likely cause of
A

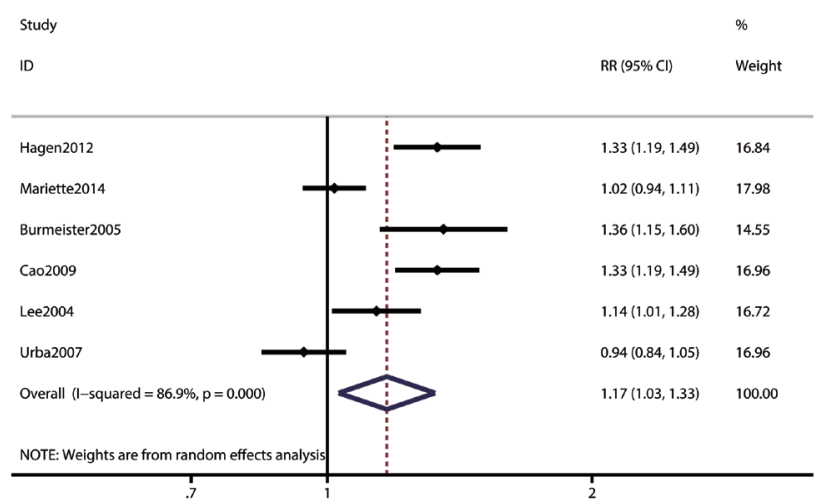

$\mathrm{B}$

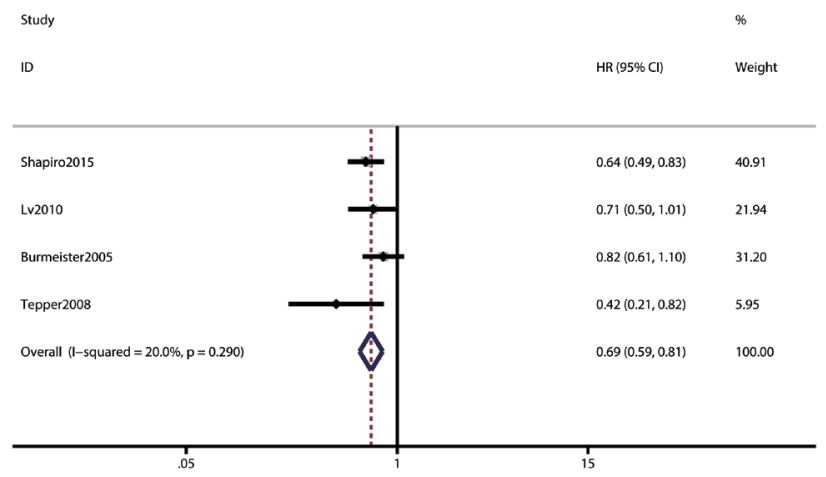

Figure 3: Meta analysis comparing the secondary outcomes of patients receiving neoadjuvant chemoradiotherapy plus surgery and surgery alone (A: R0 resection; B: progression-free survival).

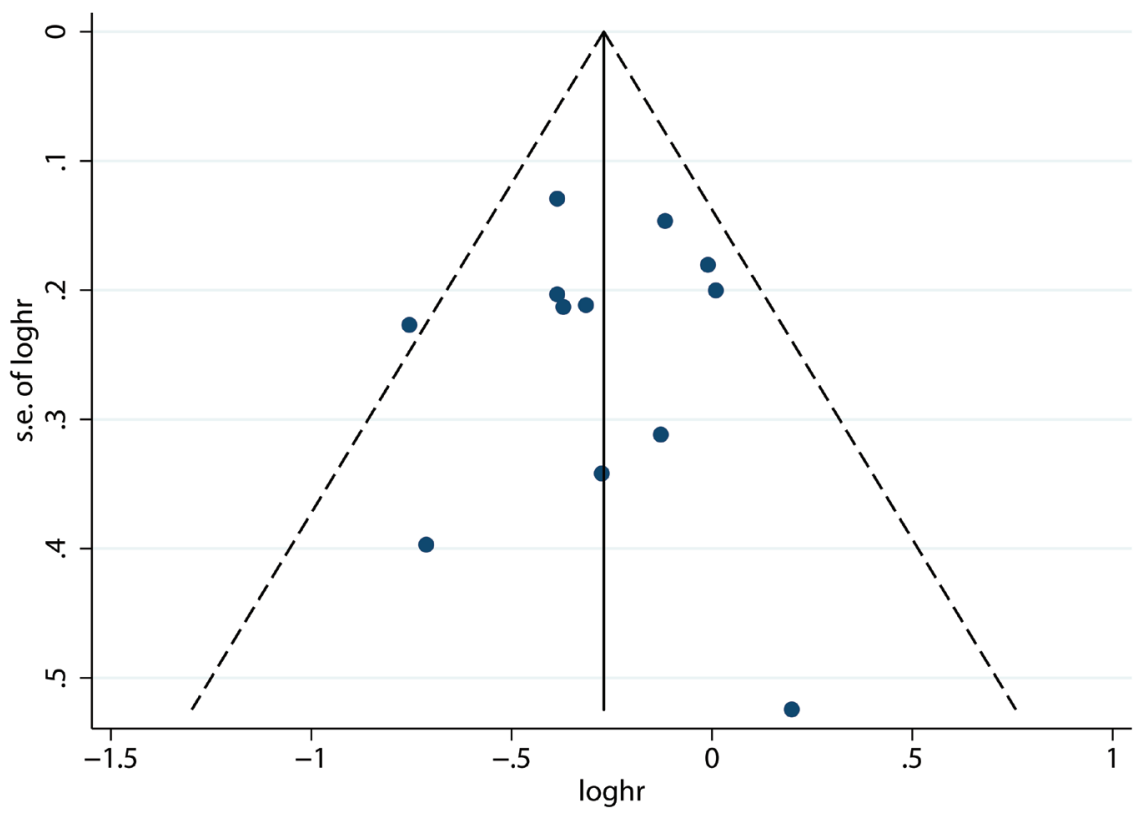

Figure 4: Funnel plot for publication bias of overall survival between neoadjuvant chemoradiotherapy plus surgery and surgery alone. 
improved $\mathrm{R} 0$ resection. In addition to $\mathrm{R} 0$ resection rate, our meta-analysis also investigated progression-free survival which is rarely published in previous metaanalysis. Compared with surgery alone, concurrent NCRT plus surgery significantly improved the progression-free survival. This finding also demonstrated that concurrent NCRT plus surgery could improve therapeutic outcomes.

Although subgroup analysis based on postoperative complications failed to be conducted, the included studies showed that treatment-related complications in the NCRT group had no significant difference from that of the surgery alone group $[13,17]$. In addition, loss to followup was low (ranging from $0.4 \%$ to $4.2 \%$ ), thus the result from our study is robust.

Several potential limitations of our meta-analysis should also be acknowledged. At first, since most studies included patients without clear identification of tumornode-metastasis (TNM) classification, the subgroup based on TNM classification could not be achieved. In addition, as the primary endpoint was overall survival, the difference of complications between NRCT plus surgery group and surgery alone group was not clear.

In conclusion, concurrent NCRT improves overall survival, progression-free survival and $\mathrm{R} 0$ resection rate in patients with esophageal cancer. This improvement is statistically significant and clinically relevant for SCC but not for AC subtypes. Concurrent NCRT followed by surgery should be viewed as a standard care for patients with resectable esophageal squamous cell carcinoma. Further well-designed multicenter RCTs are warranted to verify the beneficial effect.

\section{MATERIALS AND METHODS}

\section{Search strategy}

A comprehensive literature search of Pubmed, and Web of Knowledge was conducted up to the end of August 2016. The following search formula were used: (([esophageal ] OR [oesophageal] OR [esophagus] OR [oesophagus]) AND ([neoplasms] OR [cancer] OR [carcinoma]) AND ([chemotherapy] OR [radiotherapy] OR [chemoradiotherapy] OR [combined modality therapy] OR [adjuvant]) AND [neoadjuvant]). The searches were limited to articles describing RCTS and published in English. In order to identify further additional studies, manual searching of reference lists was performed.

\section{Study selection}

Articles included should fit all the following criteria: (1) Studies were designed as RCTs; (2) compared concurrent NCRT with surgery alone were considered; (3) the outcome of interest was defined as overall survival, progression-free survival, or R0 resection rate; and (4) the sample size, hazard ratio (HR) and their $95 \%$ confidence interval (CI), or data that would allow those findings to be inferred, was presented. If several publications reporting on the same population data met our criteria, the one with the longest follow-up period was selected.

\section{Data extraction and outcome measures}

The primary outcome was overall survival. The secondary outcomes were progression-free survival and $\mathrm{R} 0$ resection rate, which was defined by a tumor-free resection margin. Two authors (Baoxing Liu and Yacong Bo) independently extracted the following data from each eligible study, and discrepancies were resolved by a third investigator: first author, year of publication, number of patients randomized, and those who received chemoradiotherapy or surgery, HR for overall survival and progression-free survival, the total number of participants for each study, and the number of patients for $\mathrm{R} 0$ resection.

\section{Statistical analysis}

The meta-analysis was performed using STATA software (version 12.0; StatCorp, College Station, TX, USA) and $P<0.05$ was considered as statistically significant. Overall survival and progression-free survival were measured with a hazard ratio (HR), while the R0 resection rate was measured using risk ratios (RR). If permitted, HR and the $95 \%$ confidence interval (CI) were obtained directly from the article; otherwise, they were calculated using the methods of Parmar, [20] Tierney, [21] and Williamson, [22] which use number of events and Kaplan-Meier survival curves to estimate the HR and $95 \%$ CI. The chi-square test and $\mathrm{I}^{2}$ test were used to assess heterogeneity, with $P<0.05$ and/or $I^{2}>50 \%$ representing significant heterogeneity, and the random-effect model was selected. Otherwise, a fixed-effect model was applied [23]. Subgroup analyses were applied to evaluate potential effect modification of variables including geographic locations, and histological type (SCC and AC). Begger's Funnel plots and Egger's tests were performed to assess the publication bias [24, 25].

\section{CONFLICTS OF INTEREST}

No potential conflicts of interest were disclosed.

\section{REFERENCES}

1. Torre LA, Bray F, Siegel RL, Ferlay J, Lortet-Tieulent J and Jemal A. Global cancer statistics, 2012. CA Cancer J Clin. 2015; 65:87-108. 
2. Loomis D, Huang $\mathrm{W}$ and Chen G. The International Agency for Research on Cancer (IARC) evaluation of the carcinogenicity of outdoor air pollution: focus on China. Chinese Journal of Cancer. 2014; 33:189-196.

3. Palladino-Davis AG, Mendez BM, Fisichella PM and Davis CS. Dietary habits and esophageal cancer. Diseases of the esophagus. 2015; 28:59-67.

4. Kumagai K, Rouvelas I, Tsai JA, Mariosa D, Klevebro F, Lindblad M, Ye W, Lundell L and Nilsson M. Metaanalysis of postoperative morbidity and perioperative mortality in patients receiving neoadjuvant chemotherapy or chemoradiotherapy for resectable oesophageal and gastro-oesophageal junctional cancers. The British journal of surgery. 2014; 101:321-338.

5. Mariette C, Piessen G and Triboulet JP. Therapeutic strategies in oesophageal carcinoma: role of surgery and other modalities. The Lancet Oncology. 2007; 8:545-553.

6. Wang DB, Zhang X, Han HL, Xu YJ, Sun DQ and Shi ZL. Neoadjuvant chemoradiotherapy could improve survival outcomes for esophageal carcinoma: a meta-analysis. Digestive diseases and sciences. 2012; 57:3226-3233.

7. Walsh TN, Noonan N, Hollywood D, Kelly A, Keeling N and Hennessy TP. A comparison of multimodal therapy and surgery for esophageal adenocarcinoma. The New England journal of medicine. 1996; 335:462-467.

8. Shapiro J, van Lanschot JJ, Hulshof MC, van Hagen P, van Berge Henegouwen MI, Wijnhoven BP, van Laarhoven HW, Nieuwenhuijzen GA, Hospers GA, Bonenkamp JJ, Cuesta MA, Blaisse RJ, Busch OR, et al. Neoadjuvant chemoradiotherapy plus surgery versus surgery alone for oesophageal or junctional cancer (CROSS): longterm results of a randomised controlled trial. The Lancet Oncology. 2015; 16:1090-1098.

9. van Hagen P, Hulshof MC, van Lanschot JJ, Steyerberg EW, van Berge Henegouwen MI, Wijnhoven BP, Richel DJ, Nieuwenhuijzen GA, Hospers GA, Bonenkamp JJ, Cuesta MA, Blaisse RJ, Busch OR, et al. Preoperative chemoradiotherapy for esophageal or junctional cancer. The New England journal of medicine. 2012; 366:2074-2084.

10. Mariette C, Dahan L, Mornex F, Maillard E, Thomas PA, Meunier B, Boige V, Pezet D, Robb WB, Le Brun-Ly V, Bosset JF, Mabrut JY, Triboulet JP, Bedenne L and Seitz JF. Surgery alone versus chemoradiotherapy followed by surgery for stage I and II esophageal cancer: final analysis of randomized controlled phase III trial FFCD 9901. Journal of clinical oncology. 2014; 32:2416-2422.

11. Lv J, Cao XF, Zhu B, Ji L, Tao L and Wang DD. Longterm efficacy of perioperative chemoradiotherapy on esophageal squamous cell carcinoma. World journal of gastroenterology. 2010; 16:1649-1654.

12. Burmeister BH, Smithers BM, Gebski V, Fitzgerald L, Simes RJ, Devitt P, Ackland S, Gotley DC, Joseph D, Millar J, North J, Walpole ET and Denham JW. Surgery alone versus chemoradiotherapy followed by surgery for resectable cancer of the oesophagus: a randomised controlled phase III trial. The Lancet Oncology. 2005; 6:659-668.

13. Cao XF, He XT, Ji L, Xiao J and Lv J. Effects of neoadjuvant radiochemotherapy on pathological staging and prognosis for locally advanced esophageal squamous cell carcinoma. Diseases of the esophagus. 2009; 22:477-481.

14. Lee JL, Park SI, Kim SB, Jung HY, Lee GH, Kim JH, Song HY, Cho KJ, Kim WK, Lee JS, Kim SH and Min YI. A single institutional phase III trial of preoperative chemotherapy with hyperfractionation radiotherapy plus surgery versus surgery alone for resectable esophageal squamous cell carcinoma. Annals of oncology. 2004; 15:947-954.

15. Tepper J, Krasna MJ, Niedzwiecki D, Hollis D, Reed CE, Goldberg R, Kiel K, Willett C, Sugarbaker D and Mayer R. Phase III trial of trimodality therapy with cisplatin, fluorouracil, radiotherapy, and surgery compared with surgery alone for esophageal cancer: CALGB 9781. Journal of clinical oncology. 2008; 26:1086-1092.

16. Natsugoe S, Okumura H, Matsumoto M, Uchikado Y, Setoyama T, Yokomakura N, Ishigami S, Owaki T and Aikou T. Randomized controlled study on preoperative chemoradiotherapy followed by surgery versus surgery alone for esophageal squamous cell cancer in a single institution. Diseases of the esophagus. 2006; 19:468-472.

17. Urba SG, Orringer MB, Turrisi A, Iannettoni M, Forastiere A and Strawderman M. Randomized trial of preoperative chemoradiation versus surgery alone in patients with locoregional esophageal carcinoma. Journal of clinical oncology. 2001; 19:305-313.

18. Hsu PK, Chien LI, Huang CS, Hsieh CC, Wu YC, Hsu WH and Chou TY. Comparison of survival among neoadjuvant chemoradiation responders, non-responders and patients receiving primary resection for locally advanced oesophageal squamous cell carcinoma: does neoadjuvant chemoradiation benefit all? Interactive cardiovascular and thoracic surgery. 2013; 17:460-466.

19. Kranzfelder M, Schuster T, Geinitz H, Friess H and Buchler P. Meta-analysis of neoadjuvant treatment modalities and definitive non-surgical therapy for oesophageal squamous cell cancer. The British journal of surgery. 2011; 98:768783.

20. Parmar MK, Torri V and Stewart L. Extracting summary statistics to perform meta-analyses of the published literature for survival endpoints. Stat Med. 1998; 17:28152834.

21. Tierney JF, Stewart LA, Ghersi D, Burdett S and Sydes MR. Practical methods for incorporating summary time-toevent data into meta-analysis. Trials. 2007; 8:16.

22. Williamson PR, Smith CT, Hutton JL and Marson AG. Aggregate data meta-analysis with time-to-event outcomes. Stat Med. 2002; 21:3337-3351.

23. Higgins JPT, Thompson SG, Deeks JJ and Altman DG. 
Measuring inconsistency in meta-analyses. British Medical Journal. 2003; 327:557-560.

24. Begg CB and Mazumdar M. Operating characteristics of a rank correlation test for publication bias. Biometrics. 1994; 50:1088-1101.
25. Egger M, Davey Smith G, Schneider M and Minder C. Bias in meta-analysis detected by a simple, graphical test. BMJ. 1997; 315:629-634. 